\title{
SCHUR-HARMONIC CONVEXITY FOR DIFFERENCES OF SOME SPECIAL MEANS IN TWO VARIABLES
}

\author{
YING WU, FENG Qi AND HUAN-NAN SHI
}

Abstract. In the paper, the authors find Schur-harmonic convexity of linear combinations of differences between some means such as the arithmetic, geometric, harmonic, and root-square means, and establish some inequalities related to these means and differences.

Mathematics subject classification (2010): Primary 26E60; Secondary 26B25, 26D20. Keywords and phrases: Schur-harmonic convexity, difference, mean.

\section{REFERENCES}

[1] A. W. Marshall, I. Olkin, And B. C. ARnold, Inequalities: Theory of Majorization and its Applications, 2rd Ed., Springer Verlag, New York-Dordrecht-Heidelberg-London, 2011. http://dx.doi.org/10.1007/978-0-387-68276-1.

[2] H.-N. SHI, D.-M. LI, AND J. ZHANG, Refinements of inequalities among difference of means, Int. J. Math. Math. Sci. 2012 (2012), Article ID 315697, 15 pages. http://dx.doi.org/10.1155/ 2012/315697.

[3] H.-N. ShI, J. Zhang, AND D.-M. LI, Schur-geometric convexity for differences of means, Appl. Math. E-Notes 10 (2010), 275-284.

[4] I. J. TANEJA, On a difference of Jensen inequality and its applications to mean divergence measures, RGMIA Res. Rep. Coll. 7 (2004), no. 4, Art. 16. http://rgmia.org/v7n4.php.

[5] I. J. TANEJA, Refinement of inequalities among means, J. Comb. Inf. Syst. Sci. 31 (2006), no. 1-4, 343-364.

[6] B.-Y. WANG, Foundations of Majorization Inequalities, Beijing Normal Univ. Press, Beijing, China, 1990. (Chinese)

[7] S.-H. WU AND L. DeBnath, Inequalities for differences of power means in two variables, Anal. Math. 37 (2011), no. 2, 151-159. http://dx.doi.org/10.1007/s10476-011-0203-z.

[8] Y. WU AND F. QI, Schur-harmonic convexity for differences of some means, Analysis (Munich) 32 (2012), no. 4, 263-270. http://dx.doi.org/10.1524/anly.2012.1171.

[9] W.-F. XIA AND Y.-M. CHU, Schur-convexity for a class of symmetric functions and its applications, J. Inequal. Appl. 2009 (2009), Article ID 493759, 15 pages. http: //dx.doi .org/10.1155/ 2009/493759. 